\title{
Peertechz
}

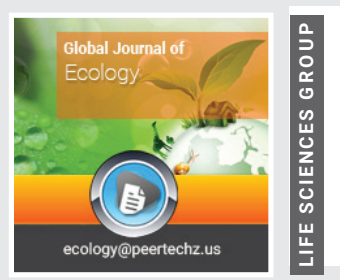

\section{Towards effective monitoring of sand mining sites and post management techniques in sand dredged environment of Akwa Ibom State, Nigeria}

\author{
Abraham $\mathrm{CM}^{1}$, Essien $\mathrm{K}^{1}$, Umoh EU ${ }^{2}$, Umoh EC ${ }^{1}$, \\ Ehiremem LE' ${ }^{1}$ Akpan $\mathrm{V}^{3}$ and William $\mathrm{NI}^{1 *}$ \\ ${ }^{1}$ Department of Geography and Natural Resource Management, University of Uyo, Uyo, Nigeria \\ ${ }^{2}$ Clement Isong Centre for Development Studies, University of Uyo, Uyo, Nigeria \\ ${ }^{3}$ Akwa Ibom State Polytechnic, Ikot Osura, Nigeria
}

Received: 18 October, 2021

Accepted: 01 November, 2021

Published: 02 November, 2021

*Corresponding author: William NI, Department of Geography and Natural Resource Management, University of Uyo, Uyo, Nigeria, Tel: +2349058884251;

E-mail:williamnyetiobong@gmail.com

Keywords: Effective; Monitoring; Sand mining; Postmanagement; Environment

Copyright License: (c) 2021 Abraham CM, et al. This is an open-access article distributed under the terms of the Creative Commons Attribution License, which permits unrestricted use, distribution, and reproduction in any medium, provided the original author and source are credited.

https://www.peertechzpublications.com

\section{Check for updates}

\section{Abstract}

The study examined Sand Dredged Environment of Akwa Ibom State, Nigeria towards effective monitoring of sand mining mites and post-management techniques. Multi-stage random sampling was used to select nine (9) Local Government Areas and three (3) communities from the selected local Government Areas in Akwa Ibom State. Primary data were collected with structured questionnaires and focus group discussion. The study reveals that post-management guidelines of sand mining environment was not adopted in the study area to the failure in management of the environment in which a larger expanse of agricultural land have been converted to waste land and borrow pit. This work found that acquisition of sand mining permit was grossly ignored among sand miners in some mining communities, whereas other miners who obtained their permit deliberately hired too many dredgers in their allocated sand mining sites and the stakeholders mandated to monitor sand mining sites did not visit the sites and were relatively unaware of the illegal businesses going on in the sand mining sites. Chi-square was used to examine the impact of stakeholders on management of sand mining environment. The result indicated that a value of 204.565 at $p<0.05$ was obtained and it was concluded that stakeholders in the solid mineral exploration industry should re-direct their interest toward post-management of sand mining environment so as to restore degraded ecosystem for further land use purposes.

\section{Introduction}

Natural Resource sustainability cannot be over-emphasized given the rate of competitive demand of natural resources and its associated environmental degradation. Several studies over the years have focused on socio-economic impact of sand mining with little or no discussion on post-management of sand mining environment. The attitude of sand miners toward the abandonment of sand mining site is very appalling and contradicts the sustainable environmental management. As soon as the sand mining sites are exploited, and no effort is made to either landfill the degraded sites or restore the ecosystem including the biodiversity, water quality and many others, the entire environment will suffer a lot of devastations [1].
Sand mining has also been a subject of contemporary research and discussions It was Various scholars have conducted rigorous research on the subject matter ranging from the socioeconomic implication, environmental impact of sand mining in both developed and developing economy [2]. The general mining of environmental resources and that of river sand, rock minerals, laterite sands and gravels in particular is a stimulus for economic development and at the same time a significant negative influencer of that same environment, when carried out in an inappropriate and unregulated way [3].

While lands upon which we extract gravels are the solid foundation on which every land use and even land cover is developed, rivers are the arteries of the landscape, networking and integrating the impacts of change in atmospheric and terrestrial systems and delivering these to the coast. En-route 
geomorphological processes create habitats, in-stream and in riparian and floodplain environments [1]. Unfortunately, the extensive use of sand and the increase in mining activities have negative environmental impacts on both the local and global levels [4] and urgent measures are needed to limit these effects. The environmental consequences vary, in part, depending on where sand is mined and sourced. Three main natural sand sources include pit sand, river sand, and sea sand [5]. To compound the environmental consequences of legal mining and sourcing, illegal activities associated with sand mining and its transportation have been reported in many parts of the world. They most commonly occur in underdeveloped and developing nations (UNEP-GEAS, 2020). A study carried out by William, Abraham, Udoh (2016) reviewed the livelihood assessment of sand mining in Etinan Local Government Area. Other studies include work conducted by Jimmy [6] on degradation and collaborative management of sand mining in Etinan and Nsit Ibom, Akwa Ibom State. This study noted that sand mining using modern dredgers have exposed the physical environment to higher risk than the traditional mining method. After the mining operation in the study area, no effort was made to restore the degraded environment. Therefore, postmanagement of the mining sites was a critical challenge and currently over 80 hectares of land are degraded, abandoned and wasted in the study area. The study recommended that policy makers should implement and enforce post-management plan for management of degraded sand mining environment so as to reclaim the wasted land for agriculture and other developmental purposes.

\section{Statement of the problem}

Many centuries ago before the discovery of sand mining as a source of livelihood, the relevance of sand resources in wealth creation, building and construction was minimal since the barbarian lived in caves, rocks and forest. In those good days, men had a stronger relationship with nature in such a way that respect and recognition to the environment and the splendour of its resources were buried in the spirit of men. At this time, the geomorphic parameters of natural streams and rivers were not as rugged and unstable as they are today, rivers were good places for swimming and leisure with little or no risk of drowning. People were afraid to destroy the local stream in search for sand and gravel due to the fear of desecrating the homes of gods and goddess, and by placing such value on the ecosystem, local streams were protected and were found to be the purest and cleanest source of water.

The sudden discovery of quality sand resources in streams and land surface raised the hope of the people for development unknown to them that this development would breed environmental hazard to their immediate surroundings, farmlands and biodiversity. In their innocence, they welcomed sand exploitation with an open hands and also mortgage their future generation by privatizing sand beaches for economic gains, they believed that government as well as mining companies were interested and committed to their development. They soon realize that this was not the case, and that the two stakeholders shared a common interest in the maximization of profit and accumulation of capital at all cost at the expense of host communities.

Sand mining has destroyed several natural ecosystem and threaten food production as farmers wake up to realize that their once fertile farmland are converted to wasteland, gully erosion, biodiversity disappearance, contamination of ground water, surface water pollution by chemicals from mining, landslides, coastal erosion, flooding and many others have mounted serious weight on environmental stability [7]. Sand mining has also destroy roads in local communities, threatened agricultural productivity and exposes concerned vulnerable communities to high risk of death and health challenges. Although, the Nigerian government has devised statutory guidelines to address the associated risks of human activity on the environment, the challenges involved in management of degraded sand mining sites are traceable to the fact that there is no clear cut statutory guidelines and monitoring institution to ensure that polluted rivers as well as degraded physical environment are reclaimed for further future purposes. The need to restore this ecosystem is very essential as a greater part of the state's landmass is lost to sand mining. T The problem of environmental, economic and social impacts arising from increased sand mining activity, especially in the sphere of watershed scale cannot be overemphasized.

The issue is now that with the level of ecological degradation, how would the people affected cope with the loss of their farmland, community forest and source of water and to what extent has the seeming ecological collapse contributed to the challenges of community development in Akwa Ibom State. The following questions would be addressed;

1. To examine the existing management plan for restoring degraded sand mining sites in Akwa Ibom State

2. To assess the various stakeholders overseeing the management of sand mining environment in the study area

3. To ascertain the challenges facing management of sand mining environment in Akwa Ibom State

4. To suggest ways of managing degraded sand mining sites for sustaianbility.

\section{Sand mining operation}

Mining of sand involves various techniques including in-stream, opencast excavation and so on. In-stream sand mining entails the removal of sand materials directly from the stream, ocean, lake and other fresh water bodies. This can be done either through the use of shovel or any other crude tools to extract sand from the river bed or with a modern-day dredger and other machines to augment production scale [8]. Nevertheless, the rural people often make use of canoes, metal buckets and shovels due to low skill in handling industrialscale machines. Once at a right spot, they dive with the bucket into the water, dragging the bucket along the river beds and capturing the sand into the bucket and when the bucket is filled to its capacity, they swim out of the water. The contents of sand 
in the bucket are then emptied into the canoe that floats on the water surface. The canoe when filled to capacity is paddle away from the river and emptied to the shore, whence the sand products are being taken by tippers and trucks to their various destinations. This form of sand mining is practice virtually in all part of the state where fresh water bodies exist.

The open cast method or pit excavation (Borrow pit) involves the removal of the surface material (Overburden) to expose the desired deposit of sand buried underneath the overburden. The exposed material is then excavated laterally and horizontally depending on the depth and areal extent of the deposited sand [9]. Generally, it involves digging and throwing up of sand into a vehicle or unto the surface by either the use of crude implements or loaders but where these processes are limited due to the access of these implements or huge machines, the sand excavated materials or product are conveyed manually by the use of headpans and buckets of their storage points by women and younger people who are paid on daily basis for their abilities in carrying various quantities $[8,10]$. Much of the borrow pit mining are handled by road construction firms for infrastructural development and sand are subsequently exploited at industrial scale.

After exploration and identification of a mining site, a permit and EIA is required by the state government as we as a pre-requisite for industrial sand mining. This often help in ensuring environmental sustainability and illegalities. This form of sand mining is common in uyo, Oron, Itu, Ikot Abasi etc. Off-shore riverbed excavation is also practiced in the state whereby a receding stream accumulates a large deposit of sediment over million years of geologic age and subsequently exposed the transported materials to the top soil layer. In most cases, they are found in farmland around receding stream and the various product ranges from gravel, sharp sand and pure plastering sand as the sediment had undergone thorough erosive processes. This form of sand is influence by erosional processes, transport of bed load, deposition following reduction in fluvial energy in a stream. In Abak L.G.A, this type of sand has been discovered recently and exploitation is becoming very aggressive in the area. In Ibeno, around Ibaka community, this resource is found in a massive scale on farmlands along receding stream. It has been recognized as the purest plastering sand for constructional purposes and its demand is very high.

\section{Why post-management of sand mining environment ne- cessary}

Sand and gravel are extracted globally and they account for the largest volume of solid minerals extracted by erosive processes [6]. The demand for sand and gravel in development today cannot be underestimated and these resources have become the major raw materials for building and road constructional industry all over the world. As development heightened, the demand for sand and gravel correspondingly increases. For instance, in Dubai, the famous palm Jumeirah, an artificial set of islands utilized 186.5 million $\mathrm{m}^{3}$ of sand and 10 million $\mathrm{m}^{3}$ of rocks worth US\$ 12 billion [11]. Many nations no longer have sufficient construction sand due to their domestic consumption levels. For instance, Dubai's marine sand resources is near depletion only relying on sand importation from other countries including Australia. Recently, Singapore has imported about 517 million tonnes of sand from Indonesia, Malaysia, Thailand and Cambodia to meet its construction demand and has remained the largest importer of sand worldwide [11] (Figures 1,2).

\section{Challenges facing management of sand mining environ- ment}

Government has made series of effort in management of sand mining environment and the results seemed to be unyielding due to certain challenges such as:

i. Aggressive behaviour of sand miners: The behavioural trait of sand miners are extremely aggressive and they are vulnerable to breaking of rules. Sand miners in many part of Akwa Ibom State are too violent and uncultured and this has been one of the reason for accelerated environmental degradation. Unless government intervene by ensuring that behavioural change is made possible among the local miners, sustainability in resource use would be a mirage.

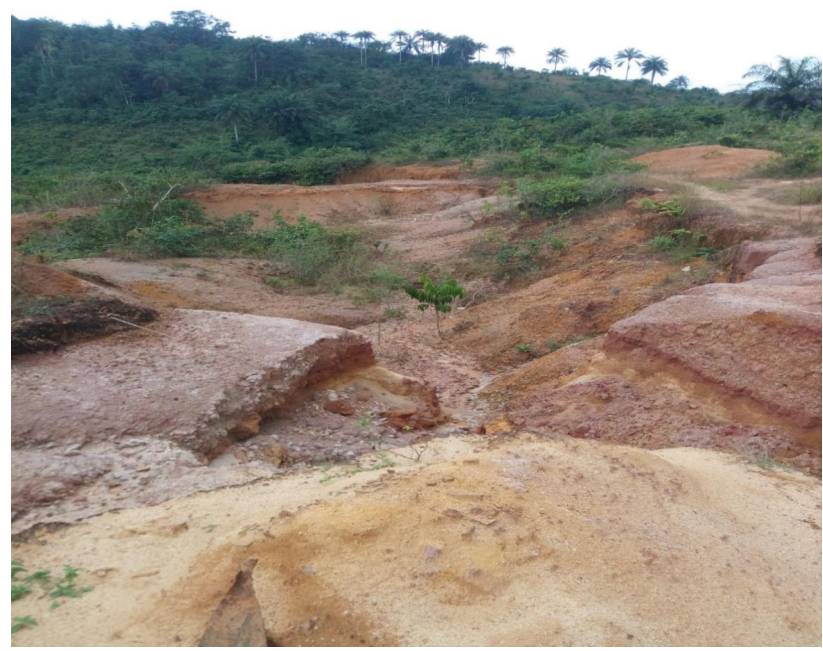

Figure 1: Degraded and abandoned sand mining environment at Anyam Community, Nsit Ibom.

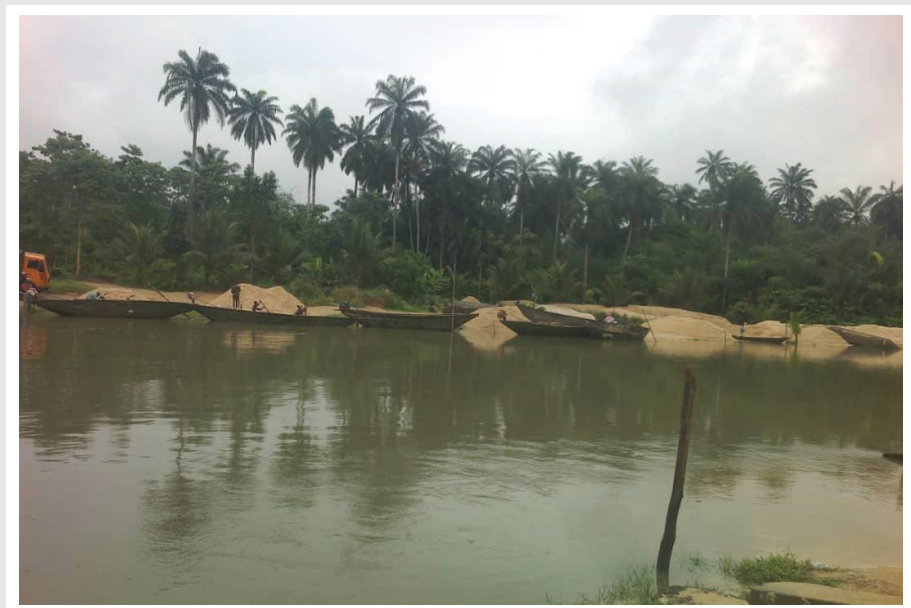

Figure 2: Polluted Local Stream in Nkana Iman, Etinan. 
ii. Poor monitoring culture of government agencies: The need for monitoring of sand mining activities is very essential. For the mere fact that laws are made, does not guarantee compliance most especially in African setting where rules are likely to be breached. Strict enforcement of rules is required so as to discourage the potential defaulters from taking actions that could affect resource management and sustainability.

iii. Conflict in Decision making among stakeholders: Most times decision are taken following a top-down approach and the local people are excluded from deciding their fate in resource management. Such kind of decision making does not promote sustainability because the local people may not be satisfied with the policies given out to them and thus may choose to bend the rules in order to suit their individual's interest. For instance, the State government in Akwa Ibom State issued mining permit to prospective local miners, but since the local community stakeholders were not consulted in the development, as such miners refuse registering with the state and rather choose to indulge in illegal mining for the fear of their actions being monitored. Following this, Jimmy [6] suggested that collaborative management of sand mining should be embraced so that every stakeholders would contribute meaningfully and distinctly in management of sand mining environment.

iv. Excessive dredgers in sand mining sites: The greater the number of dredgers used in sand mining site at a time, the more the level of degradation. In Ekpene Ukpa Beach, Etinan LGA in Akwa Ibom State, about 72 dredgers were found in a single sand mining site and this forced the state government to arrest the miners since the level of degradation was too alarming. Besides, other sand mining sites have more than 10 dredgers operating at the same time. Using too many dredgers at a time has the capacity to destabilise the ecosystem, deepen and widen the riverbed and as well as other environmental risks.

v. Illegal sand mining: The level of illegal sand mining in Sub-Saharan Africa is very high including Ghana, Kenya, South Africa and others [12]. Akwa Ibom State is seriously affected by the activities of illegal miners who are not legally recognised by the government. In the study area, the population of registered sand miners is low compared to the unregistered miners and this make it more difficult for government to manage the coastal resource.

\section{Study area}

This study was carried out in Akwa Ibom State. Akwa Ibom State is in the southern part of Nigeria. Geographically, Akwa Ibom State is bordered by Rivers State on the West, Cross River State on the East as well as Bight of Bonny (Atlantic Ocean) on the South. The entire region lies in the tropical rain forest belt and has two distinct season-rainy and dry season. The predominant vegetation in the region are but not limited to
Nypa Palm, Oil Palm, Raffia Palm, ferns, shrubs, Rhizophora racemosa (red mangrove), white mangrove and variety of economic trees. Akwa Ibom State has enormous natural resources such as clay, glass sand, palm produce, crude oil, and agricultural produce. Forest resources are abundant in the area such as reptiles, amphibians and wide variety of wildlife. Similarly, the region is also blessed with abundant cash crops and food crops. Cash crops ranges from oil palm, rubber, cocoa, coconut and so on, whereas, food crops ranges from rice, cassava, maize, plantain, cocoyam, water yam, banana, okro as well as wild fruit such as Nyatet- Malsobotga dusenie, Mkpantuk-shnsepalum dwafian etc. (Usoro \& Akpan, 2010) .

The climate condition of this area is largely controlled by its location along the coast of the Atlantic Ocean. The two prevalent air masses that blows over the area are the warm, humid tropical maritime and associated south-westerly trade winds (monsoon) which blows across the Atlantic Ocean. These winds usher in the wet season between April and October. The second is the cold, dry dusty tropical continental air masses with the associated harmattan winds which blow from the Sahara. It is called the North-East Trade winds and is experienced between December and February.

In terms of the geology of the region, two major geological formation are identified: the Younger Benin formation which covers the low-lying part of the state. Another formation is the beach ridge complex and alluvial deposits which occurs along the shores from Imo estuary, Kwa to Cross River estuary. This environment is characterized by a set of geomorphic features such as point bars, river channel, levees, back swamps among others (Akpabio, 2013). The people of Akwa Ibom State are predominantly into trading, fishing and craft work. Besides, the region has abundant crude oil, natural gas, fine sand, laterite, sharp sand, water resources and many other essential resources. Due to the abundance of resources in the region, several companies have trooped in including Exxon Mobil, Septa Energy, fishing companies, sand dredging companies, petrochemical industries, agro-allied industries and other cottage industries.

\section{Materials and methods}

Data for the study was obtained primarily from the use of structured questionnaire, personal observation of mining sites and through guided or semi-structured interviews, focus group discussions at village councils and this was complemented by secondary data. Three hundred and ninety six (396) structured questionnaires were administered to various targeted population which included sand miners, community council of chiefs, local indigene, sand distributors and association of sand miners. Percentage and frequency tables of responses from respondents were used in presenting the results of the study. Chisquare statistical technique (using SPSS) was employed in testing for the impact of stakeholders on management of sand mining environment in Akwa Ibom State. Stratified random sampling was adopted whereby the sample unit was taken based on the three (3) senatorial district found in the state. Three LGAs were chosen for each senatorial district and thus generating a total of nine Local Government Unit. Nine Local 
Government Areas were sampled out of 31 LGAs of the State. These included Etinan, Nsit Ibom, Ibesikpo Asutan, Etim Ekpo, Abak, Oruk Anam, Ibeno, Oron, Udung Uko. Furthermore, 3 villages with active sand mining were purposively selected for the study. This made up a total of 27 villages altogether. The sampled villages included: Obot Idim, Afaha Udoeyop, Nung Oku Akpasima, Inua Eyet Ikot Okposo, Upenekang, Iwuchang, Ekpene Ukpa, Nkana Iman, Ndon Etim, Oboyo Ikot Ita, Anyam, Nditung, Ikot Okoro, Ibesit Okpokoro, Ikot Ekpuk, Ibaka, Eyo Abasi, Eyotong, Eyo Okop Nnung, Eyo Atai, Ekim, Manta/ Midim, Ediene Abak, Ukpom Abak Plate 1.

\section{Results and discussion}

Table 1 revealed that the detail of age composition of miners ranged from $21-25(35.5 \%)$ fall under the vibrant population with a youthful age group. $21 \%$ of the population fall within 36 and above, $14 \%$ fall within $15-20,15 \%$ fall within $26-30$, and $14.5 \%$ fall within $31-35$. This implies that the youthful population are more involved in sand mining activities than the older ones. From the field survey as revealed in table $4.1,95 \%$ of the sampled respondents were male and only $5 \%$ were females. This revealed that males involved in sand mining activities more than females. From the marital status of respondent, it shows that $45 \%$ of the respondent sampled were single, $35 \%$ were married, $14.5 \%$ were divorced, $0 \%$ were widow and $5.5 \%$ of the respondent were widower. The result indicates that students and some shows the educational level of the respondent, 176 people sampled which makes $44 \%$ have attended primary school, 202 persons who make up 51\% have attended secondary school, 12 persons which makes up $3 \%$ have post-secondary education and 4 persons which make up $2 \%$ have no formal education. Most of the respondents who participated in the sand mining operations obtained some

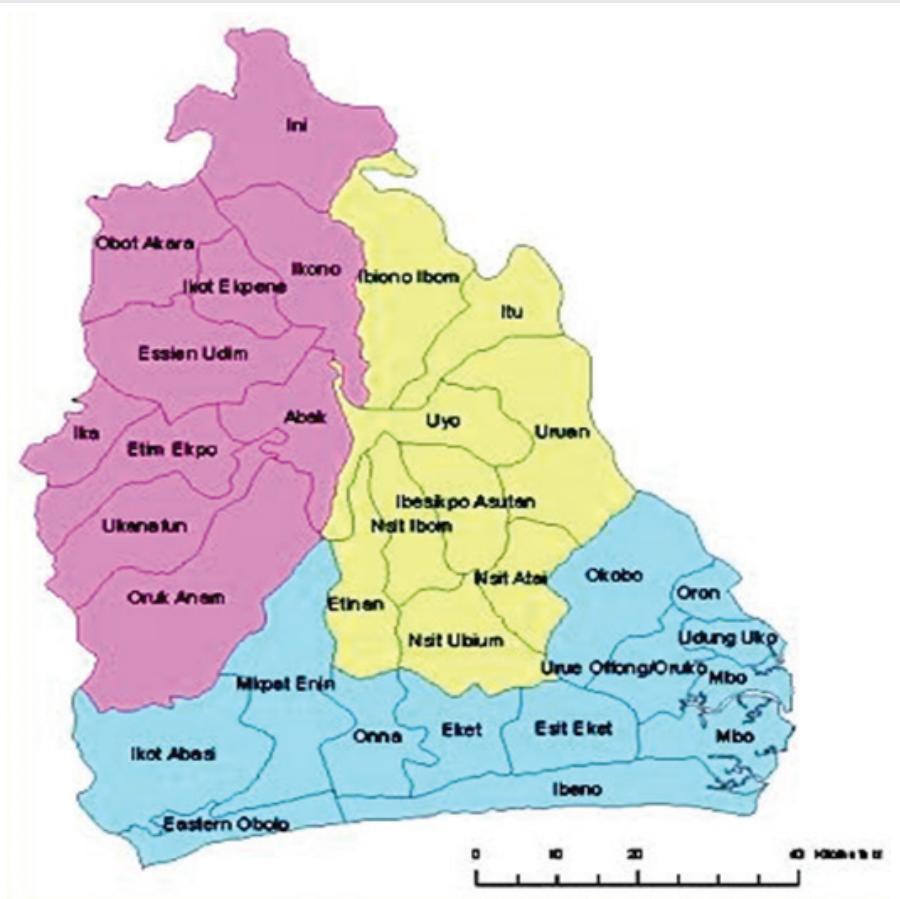

Plate 1: Akwa Ibom State Showing Local Government in their Senatorial Groupings Source: Ministry of Lands and Housing, Akwa Ibom State.
Table 1: Age, Sex, Marital Status and Educational Level of the Respondents.

\begin{tabular}{|c|c|c|}
\hline Age & Number of Respondents & Percentage \\
\hline $15-20$ & 54 & 14 \\
\hline $21-25$ & 139 & 35.5 \\
\hline $26-30$ & 60 & 15 \\
\hline $31-35$ & 58 & 14.5 \\
\hline 36 and above & 81 & 21 \\
\hline Total & 392 & 100 \\
\hline \multicolumn{3}{|l|}{ Sex } \\
\hline Sex & Number of Respondent & Percentage \\
\hline Male & 372 & 95 \\
\hline Female & 20 & 5 \\
\hline Total & 392 & 100 \\
\hline \multicolumn{3}{|l|}{ Marital status } \\
\hline Marital status & Number of Respondent & Percentage \\
\hline Single & 180 & 45 \\
\hline Married & 140 & 35 \\
\hline Divorced & 60 & 30 \\
\hline Widower & 20 & 10 \\
\hline Widow & 0 & 0 \\
\hline Total & 392 & 100 \\
\hline \multicolumn{3}{|l|}{ Educational level } \\
\hline Primary education & 176 & 44 \\
\hline Secondary education & 202 & 51 \\
\hline Tertiary education & 10 & 3 \\
\hline No formal education & 4 & 2 \\
\hline Total & 392 & 100 \\
\hline
\end{tabular}

levels of education especially secondary. These outcomes imply that the age group, marital status, gender and educational levels could influence involvement and capacity in sand mining activities.

Decisions on post-management of sand mining environment plays a critical role in sustainable sand mining. From Table 2, $12.6 \%$ of respondent agreed that federal government contribute significantly to management of sand mining, $22.7 \%$ on state government, $30.3 \%$ on local government area, $27.8 \%$ on association of sand miners and $6.6 \%$ on NGOs. In terms of post management of sand mining environment, $7.6 \%$ of respondents agreed that post-management strategy to be made in sand mining should incorporate imposition of ban, $20.5 \%$ on landfilling, $16.4 \%$ on polluted water treatment, $17.7 \%$ on effective monitoring and fines as well as $37.9 \%$ on environmental damage tax. In the study area, the idea of sand banning have been seriously condemn among the rural dwellers, given the level of dependence on sand beaches for livelihood. The emergence of sand banning has really affected the socio-economic development of the concerned communities. Meanwhile, majority of respondents (30\%) agreed to the idea of introducing environmental damage tax as well as other post- management options including landfilling and ecological restoration. This implies that sustainable sand mining can only be achieved through an interplay of 
Table 2: Responses on the involvement of Stakeholders in Post-Management of Sand Mining Environment.

\begin{tabular}{|c|c|c|c|}
\hline $\begin{array}{l}\text { Stakeholders in management of sand } \\
\text { mining environment }\end{array}$ & Federal Government & 50 & 12.6 \\
\hline & State government & 90 & 22.7 \\
\hline & Local government & 120 & 30.3 \\
\hline & Association of sand miners & 110 & 27.8 \\
\hline & NGOs & 26 & 6.6 \\
\hline & Total & 396 & 100 \\
\hline $\begin{array}{c}\text { Post-Management of Sand Mining } \\
\text { Environment }\end{array}$ & Imposition of ban & 30 & 7.6 \\
\hline & Land filling & 81 & 20.5 \\
\hline & Polluted water treatment & 65 & 16.4 \\
\hline & $\begin{array}{l}\text { Effective monitoring and } \\
\text { fines }\end{array}$ & 70 & 17.7 \\
\hline & Environmental damage tax & 150 & 37.9 \\
\hline & Total & 396 & 100 \\
\hline Community-Based Management & $\begin{array}{c}\text { Community seasonal sand } \\
\text { banning }\end{array}$ & 80 & 20.2 \\
\hline & $\begin{array}{l}\text { Bank protection with } \\
\text { bamboo }\end{array}$ & 70 & 17.7 \\
\hline & Beach leasing to indigene & 85 & 21.5 \\
\hline & $\begin{array}{l}\text { Community vigilante for } \\
\text { monitoring }\end{array}$ & 60 & 15.2 \\
\hline & Community river protection & 45 & 11.4 \\
\hline & $\begin{array}{l}\text { Community pipe borne } \\
\text { water supply }\end{array}$ & 40 & 10.1 \\
\hline & Local injunction (Mbiam) & 16 & 4.0 \\
\hline & Total & 396 & 100 \\
\hline
\end{tabular}

Source: Researcher, 2021

two or more post-management options [13]. Following this, sustainable sand mining must adopt institutional guidelines in line with structural development of the degraded areas through bank protection mechanism, land filling and other measures.

Sand banning increases the risk of illegalities in concerned communities in the form of conflict, high crime rate, joblessness, poverty and hopelessness. In most communities employment rate was gradually decreasing in line with the introduction of modern-day dredging machines most especially in Ekpene Ukpa and by this the demand for skill dredgers exceeds manual labourers. This disagrees with the findings of Jimmy [6] that the contribution of sand mining to the socioeconomic development of rural communities is determined by the method of excavation tools used. The transition from artisanal sand mining to industrial-scale mining reduce labour force, promote accumulation of surplus capital to fewer sand dredgers as well as redouble environmental degradation which in turn influence agricultural productivity. This agree with the findings of Saviour [14-16] that unsustainable sand mining impede agricultural productivity.

Finally, community- based management practices are often considered to contribute to sustainable sand mining. From our findings, $20.2 \%$ of respondents agreed that community- based management of sand mining involves seasonal banning of sand mining, $17.7 \%$ agreed on bank protection with bamboo,
$21.5 \%$ agreed on beach leasing to indigenes, $15.2 \%$ agreed on community vigilante for effective monitoring, $11.4 \%$ agreed on community river protection, $10.1 \%$ agreed on community pipe borne water supply while $4 \%$ agreed on the use of local injunction (mbiam) in enforcing compliance and rule-based management system.

\section{Testing of hypothesis}

Tables 3,4 was used to test for the significance of the role played by stake holders in management of sand mining using SPSS model 24 application.

HO: The role of stakeholders in the management of sand mining environment is not statistically significant

HI: The role of stakeholders in the management of sand mining environment is statistically significant.

\section{Discussion of findings}

The research study was done with the view to assess the level of environmental degradation that arises from sand mining and the post-management options adopted in order to restore the degraded environment. An assessment of the level of degradation showed that no adequate measures was put in place to mitigate environmental degradation. The researcher reveals that post-management guidelines of sand mining environment was not adopted in the study area and this contribute to the failure in coastal resource management in which a larger expanse of agricultural land have been converted to waste land and borrow pit. It was also revealed that acquisition of sand mining permit was grossly ignored among sand miners in some mining communities, whereas other miners who obtained their permit deliberately hired too many dredgers in their allocated sand mining sites and this escalate conflict as well as uncontrollable degradation. The study also revealed that stakeholders mandated to monitor sand

Table 3: Role of Stakeholders on Management of Sand Mining Environment.

\begin{tabular}{|c|c|c|c|c|c|c|}
\hline S/N & Question & SA & A & U & D & SD \\
\hline A & Sound management decision making & 252 & 101 & 3 & 31 & 11 \\
\hline B & Resolve conflict & 196 & 158 & 14 & 18 & 13 \\
\hline C & Imposition of sanctions and levy & 163 & 192 & 6 & 20 & 17 \\
\hline D & Monitoring and Evaluation & 92 & 187 & 41 & 62 & 18 \\
\hline
\end{tabular}

*SA: Strongly Agree, A: Agree, U: Undecided, D: Disagree, SD: Strongly Disagree Source: Fieldwork, 2021

Table 4: Summary of Chi-Square Tests (Using SPSS).

\begin{tabular}{|c|c|c|c|}
\hline & Value & Df & Asymp. Sig. (2-sided) \\
\hline Chi-Square & $204.565^{\mathrm{a}}$ & 12 & .000 \\
\hline Livelihood Ratio & 203.635 & 12 & .000 \\
\hline Linear-by-Linear Association & 86.764 & 1 & .000 \\
\hline N of valid cases & 15922 & & \\
\hline
\end{tabular}

Decision: From the Chi-Square value of 204.565 was obtained and the Asymp. Sig. (2-tailed) was 0.000 . However, since the significant value of 0.000 is less than 0.05 $\mathrm{HO}$ is rejected and $\mathrm{HI}$ is accepted; thus the result was significant and can therefore be concluded that stakeholders contribute significantly to the management of sand mining environment in Akwa lbom State. 
mining sites did not visit the sites and were relatively unaware of the illegal businesses going on in the sand mining sites. The study also revealed that government have several attempt to ban mining activities in most highly degraded sand mining sites, but such policy often truncates rural livelihood. The implication is that as sand excavation activities is prohibited, rural livelihood becomes more deteriorating following issues of joblessness, hunger, high crime and youth violence. In this light, this study have challenge the notion of mono-centric governance and management where the Government issues out redundant and poverty-stricken mining strategy that does not only affect the socio-economic development of the rural dwellers but mortgage future generations needs and sustainable development. As such, the researcher advocate for a collaborative management option where the opinion and interest of the local communities is inclusive. From this, $20 \%$ of respondent agreed that proceeds from sand mining should be mainstream into rural community development in order to substitute for the huge damage concerned communities suffers, $10 \%$ agreed on community policing, $6.7 \%$ agreed on community vigilante for effective monitoring and $36.7 \%$ of respondent argued that beach right ownership should be fully open to wealthy indigene rather than outsiders so as to empower rural people and their economy.

\section{Conclusion}

Sand resources management is one of the most contentious and complicated issue in contemporary geographic research, most especially in the field of environmental and resource management It has been difficult to regulate the activities of sand miners in developing countries including Nigeria as a result of a clash of interest among relevant stakeholders and man's irresistible desire to own property. From critical observation, every common man needs a house, every owners of bungalow needs a skycrapper, every elites needs a mansion, every poor man dreams about owning a property, every village wants to be urbanized, every slum areas wants to be developed, every rural roads need accessibility, every regions clamour for infrastructural development. In spite of all these gigantic desires, policy makers have failed in organizing an institutional framework that could address both pre- management and post management of sand management environment to ensure that the needs of future generation are not mortgage for present economic benefit. They have instead placed pre-management of sand mining activities centre-stage and often overlook postmanagement of sand mining environment which constitute one of the best sustainable management practices in coastal resource management. As such, their efforts in management have been unyielding, their commitment have been unrewarded, while their competency remains questionable. The study on sand mining, environmental degradation and management in Nsit Ibom and Etinan L.G.A, have revealed that the nature of management initiative often tilt toward exposing the pre-existed environmental scar to a more widened degradation and wasteland. Government overtime have been struggling to put in place a more sustainable sand mining measure to protect both the environment and socioeconomic development of mining communities. In the midst of this struggle, the State Government have brought up a ban on sand mining so as to curtail the degradation occasioned by illegal mining activity. But, the crux of the matter remains that government in spite of this, have failed to monitor the activity of their so called "Licensed sand miners" who happens to acquire mining permit from the government for further exploitation. From this study, the researcher have revealed that those who had acquired mining permit over-exploit sand mining environment and leave behind hundreds of borrow pit un-filled. This corroborate with findings from (Akpan, 2015) on sand mining and environmental degradation in Ini L.G.A, where numerous borrow pits were abandoned with no effort to reclaim the devastated area. It is on this note that this research seek to re-awaken policy makers in mining industry to reformulate institutional framework that would address postmanagement of sand mining environment for sustainability.

\section{Recommendations}

The researcher outline recommendation to various stakeholders in the mineral and mining industry including relevant Government's Ministries, policy makers, sand dredgers, artisanal sand miners, sand marketers and researchers.

1. Sound legal framework should be drawn with appropriate sanctions to offenders, most especially illegal miners and Dredging companies that fails to observe post-management guidelines in the mining industry.

2. Strict Monitoring of sand mining operation at both the State and Local Government level to ensure environmental sustainability. Following this, the State Government should disburse sufficient fund to quicken effective monitoring. Vehicles, allowances and fuel should be provided along side other relevant facilities that would ease effective monitoring process

3. There is need to deploy 24 hour security at sand mining environment to guard sand mining site as well as punishing the defaulters. This can be made possible through the assistance of local security groups and also send reports regularly to Government's Monitoring Unit in the State Ministry of Environment for necessary action. The use of local security groups would reduce the cost of regular visiting of mining site among relevant Government's Ministries.

4. Mining should not be done on vulnerable areas which by implication, sand mining should be restricted to residential homes, gully head, steep slopes etc

5. Regular inspection and road blocks by local police authority through mounting of regular road blocks next to mining areas and along roads used by trucks, setting speed traps on speeding trucks and imposition of levies to transported vehicles due to their destructive effect on roads. The Ministry of Environment should evolve a policy compelling miners to re-invest and repair old disused mine sites to reduce occurrence of landslides. 
6. Relevant stakeholders in sand mining including government and miners should be forced to compensate farmers whose farmlands are devastated.

7. The rate of excavation and sand tonnage should be well- spelt out at each strategic mining site to control the depth of sand mining sites. Miners should follow best management practices to avoid degradation

8. Miners involving dredging machine should be monitored with strict laws and penalties on their operation.

\section{References}

1. Abraham C, William N, Akpan V (2021) Sand mining as veritable informal sec tor activity for Rural Liveihood in Abak, Akwa Ibom. Global Scientific Journal Singapore.

2. Gavriletea MD (2017) Environmental Impacts of Sand Exploitation. Analysis of Sand Market. Sustainability 9: 1118. Link: https://bit.ly/3pSLg9E

3. Blachowski J (2015) GIS-Based Spatial Assessment of Rock Minerals Mining - A Case Study of the Lower Silesia Region (Sw Poland) Mining Science 22: 07-22. Link: https://bit.ly/3pQHYE1

4. Huang B, Zhao F, Fishman T, Chen WQ, Heeren N, et al. (2018) Building Material Use and Associated Environmental Impacts in China 2000-2015. Environ Sci Technol 52: 14006-14014. Link: https://bit.ly/3nFMUZE

5. Lakshmi K, Ashwini Manjunath BT, Karthick TR, Manjunath MS (2017) Partial replacement of sea sand and desert sand in place of river sand for mortar in construction. Glob Res Dev J Eng 2: 81-85. Link: https://bit.ly/3nOxja6

6. Jimmy U (2016) Sand And Gravel Mining In Akwa Ibom State: Distribution, Environmental Degradation and Collaborative Management Initiatives. Bsc Undergraduate Project, Department of Geography and Regional Planning,

University of Uyo, Uyo

7. Atejioye AA, Odeyemi CA (2018) Analysing Impact of Sand Mining in Ekiti State,Nigeria Using GIS for Sustainable Development. World Journal of Research and Review (WJRR) 6: 26-31. Link: https://bit.ly/3ECTWFv

8. Hinton B, Keller WS (1995) Women and artisanal mining: Gender roles and the road ahead. Netherland, SWER Publishers.

9. Viju B (2012) "High court bans sand mining across Maharashtra" Times of India.

10. Robinson R (2014) Socio-cultural dimensions of supply and demand for natural aggregate-examples from the Mid-Atlantic Region, USA. U.S Geological survey report.

11. Jan De Nul Group Report (2013) Land reclamation and beach replenishment project. U.E.A, Palm Island, Dubai 2002-2008.

12. Robert K (2014) Sand mining: The deadly occupation attracting Kenyan's Youngsters. Nakuru county council, Kenya. Link: https://bit.ly/3w3u4PY

13. Akpan IE (2015) Sand mining and environmental degradation in Ini L.G.A, Akwa Ibom State. Unpublished Bsc Project, Department of Geography and Regional Planning, University of Uyo.

14. Saviour NM (2012) Environmental impacts of soil and sand mining: A Review of International Journal of Science, Environment and Technology 1: 125-134. Link: https://bit.ly/3w1kHQG

15. Kondolf GM (2008) Geomorphic and environmental effects of in-stream grave mining. Landscape and urban planning 225-243.

16. William NI, Udoh J, Abraham CM (2021) Sand Mining and Livelihood effects in Abak, Akwa Ibom State. Paper presented in Annual Association of Nigerian Geographers Conference 2016.

Discover a bigger Impact and Visibility of your article publication with

Peertechz Publications

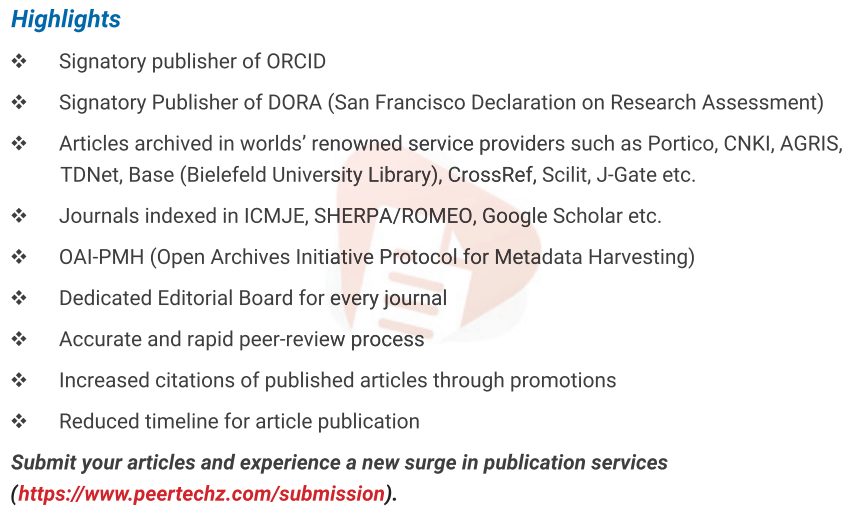

